\title{
ANALISIS KECELAKAAN LALU LINTAS STUDI KASUS JALAN RAYA PANTURA TUBAN-WIDANG KM 0,00-KM 29,00
}

\author{
Vara Kusuma Goesman P1, Boedi Rahardjo² dan Pranoto ${ }^{3}$
}

\begin{abstract}
${ }^{1}$ Universitas Negeri Malang, email: varakusuma@gmail.com
${ }^{2}$ Universitas Negeri Malang, email: boedi.rahardjo.ft@um.ac.id

${ }^{3}$ Universitas Negeri Malang, email: pranoto.tf@um.ac.id
\end{abstract}

\begin{abstract}
Abstrak: Metode deskriptif untuk mendeskripsikan karakteristik kecelakaan lalu lintas berdasarkan data sekunder tahun 2015-2018 dan penentuan lokasi blackspot dengan mengacu pada pedoman Pd-T-09-2004-B dan Metode Cummulative Summary. Metode Inferensial berupa uji korelasi dan regresi untuk mendapatkan hubungan antara kecepatan 85 persentil dengan kecelakaan serta mendapatkan model persamaan yang terbaik pada kendaraan antara sepeda motor, kendaraan ringan, dan kendaraan berat yang menyebabkan kecelakaan. Hasil penelitian menunjukaan bahwa karakteristik kecelakaan berdasarkan angka kecelakaan paling banyak terjadi pada tahun 2016 (159 kecelakaan), tipe kendaraan yang paling sering terlibat adalah sepeda motor $(54.02 \%)$, korban kecelakaan yang paling banyak adalah luka ringan $(81,78 \%)$, waktu kejadian yang paling sering pagi hari (32,16\%), hari yang paling sering terjadi adalah hari Kamis $(15,52 \%)$, usia dan jenis kelamin yang paling sering adalah laki-laki $(73,98 \%)$ dan usia 15-30 tahun (48,73\%), tipe kecelakaan yang sering terjadi adalah tabrak depan-samping $(28,68 \%)$, faktor penyebab yang paling sering terjadi adalah faktor pengemudi (91,56\%). Penentuan lokasi daerah rawan kecelakaan terletak pada STA 89+000-88+000, STA $87+000-86+000$, STA $86+000-85+000$, STA 84+000-83+000, STA 79+000-78+000, STA 78+000-77+000, STA 74+000-73+000, dan STA 72+000-71+000. Analisis hubungan antara kecepatan dengan kecelakaan pada lokasi blackspot memiliki hubungan kategori kuat adalah kendaraan sepeda motor dengan interval 0.60 $\leq \mathrm{r} \leq 0.80$. dengan model persamaan terbaik yaitu model polynomial orde $3 \mathrm{Y}=-871,61+29,294 \mathrm{x}-0,346 \mathrm{x} 2$ $+0,001 \times 3$ didapatkan nilai $\mathrm{r}=0,839$ dan $\mathrm{R} 2=0,705(70,5 \%)$ dengan kecepatan rata-rata kendaraan sepeda motor diatas $80 \mathrm{~km} / \mathrm{jam}$. sedangkan untuk kendaraan ringan dan kendaraan berat mempunyai hubungan kategori sedang dengan interval $0.40 \leq \mathrm{r} \leq 0.60$ dengan $\mathrm{R} 2$ untuk $\mathrm{LV}=0,435$ dan $\mathrm{R} 2$ untuk $\mathrm{HV}=0,377$ dibawah 0,60 sehingga tidak dapat digeneralisasikan bahwa kecepatan berpengaruh terhadap kecelakaan.
\end{abstract}

Kata-kata kunci: kecelakaan lalu lintas, kecepatan, black spot, cumulative summary,regresi

\begin{abstract}
A descriptive method to describe the characteristics of traffic accidents based on secondary data for 2015-2018 and determining the location of blackspots by referring to the Pd-T-09-2004-B guidelines and the Cummulative Summary Method. The inferential method is in the form of correlation and regression tests to get the relationship between the 85th percentile speed with accidents and to get the best equation model for vehicles between motorcycles, light vehicles, and heavy vehicles that cause accidents. The results showed that the characteristics of accidents based on the number of accidents most occurred in 2016 (159 accidents), the type of vehicle that was most often involved was motorcycles (54.02\%), the most accident victims were minor injuries (81.78\%), time the most frequent occurrence is in the morning (32.16\%), the most frequent day is Thursday (15.52\%), the most frequent age and gender are male (73.98\%) and age 15-30 years (48.73\%), the type of accident that often occurs is a front-side collision $(28.68 \%)$, the most common cause is the driver factor $(91.56 \%)$. Determination of the location of accidentprone areas is located at STA 89+000-88+000, STA 87+000-86+000, STA 86+000-85+000, STA 84+00083+000, STA 79+000-78+000, STA 78+000-77+000, STA 74+000-73+000, and STA 72+000-71+000. Analysis of the relationship between speed and accidents at the blackspot location has a strong category relationship is a motorcycle vehicle with an interval of $0.60 \mathrm{r} 0.80$. with the best equation model, namely the polynomial model of order $3 Y=-871.61+29.294 x-0.346 \times 2+0.001 \times 3$ the value of $r=0.839$ and $R 2=0.705(70.5 \%)$ with an average speed of motorcycles above $80 \mathrm{~km}$ /hour. while for light vehicles and heavy vehicles there is a moderate category relationship with an interval of $0.40 \mathrm{r} 0.60$ with $R 2$ for $L V=0.435$ and $R 2$ for $H V=0.377$ below 0.60 so it cannot be generalized that speed affects accidents.
\end{abstract}

Keywords: traffic accident, speed, black spot, cumulative summary, regression 


\section{PENDAHULUAN}

Kecelakaan merupakan penyebab kematian tertinggi di Indonesia. Jumlah korban yang cukup besar akan memberikan dampak terhadap perekonomian dan sosial yang tidak sedikit. Pada tahun 2020 diperkirakan kecelakaan lalu lintas menjadi penyebab utama kematian nomor tiga setelah penyakit jantung (Direktorat Keselamatan Transportasi Darat, 2007).

Kabupaten Tuban merupakan salah satu kabupaten yang terletak di Provinsi Jawa Timur dengan luas wilayah mencapai 1839,94 km2 dan jumlah penduduknya sebesar 1298,302 jiwa (Badan Statistik Kabupaten Tuban, 2019). Berdasarkan data kepolisisan Jawa Timur, jumlah kecelakaan di Kabupaten Tuban menempati urutan pertama dengan angka kecelakaan mencapai 1393 kejadian pada tahun 2018. Banyaknya kecelakaan yang terjadi merupakan akibat dari meningkatnya volume lalu lintas akibat dari pertumbuhan angka penduduk dan jasa pelayanan transportasi. Dimana tanpa diimbangi dengan adanya peningkatan akan keselamatan dalam berlalu lintas.

Ruas Jalan Raya Pantura Tuban-Widang KM 0,00-KM 29,00 merupakan Jalan Arteri dengan dua arah tanpa median, sekaligus sebagai jalan penghubung dan akses utama kendaraan keluar masuk dari dan ke Surabaya, Semarang, dan Jakarta. Tingginya volume kendaraan papa ruas jalan ini sudah seharusnya memiliki kondisi fisik jalan yang baik serta fasilitas perlengkapan jalan yang memadai. Ruas Jalan ini menjadi zona rawan kecelakaan di Tuban selain di kawasan hutan jati peteng Tuban-Bancar. Karena kondis jalan yang relatif datar mengakibatkan pengemudi lenggah dan melaju dengan kecepatan tinggi. Selain itu juga kondisi bahu jalan yang lebih tinggi dari samping jalan, jalan yang rusak akibat lubang, alur, jumbul mengakibatkan tingginya angka kecelakaan pada ruas Jalan Raya Pantura Tuban-Widang KM 0,00-KM 29,00.

Menurut data tahun 2015-2018, jumlah kejadian kecelakaan pada ruas jalan ini mengalami peningkatan sebanyak 508 kejadian. Akibat dari kecelakaan yaitu 130 korban meninggal dunia, 32 korban luka berat, dan 651 korban luka ringan. Tetapi kenyataannya angka kecelakaan bisa melebihi angka tersebut karena masyarakat enggan untuk melaporkan kejadian pada pihak berwajib.

Dari permasalahan yang telah dijelaskan, sangatlah penting untuk dikaji karakteristik kecelakaan ditinjai dari jumlah kecelakaan, kendaraan yang telibat, tingkat keparahan korban, waktu kejadian, usia dan jenis kelamin, tipe tabrakan, serta faktor-faktor penyebab kecelakaan. Selain itu juga penentuan lokasi blackspot, dan hubungan antara kecepatan dengan kecelakaan pada lokasi blackspot.

\section{METODE}

Jenis penelitian yang digunakan adalah deskriptif kuantitatif dan observasi. Lokasi penelitian yang ditinjau adalah pada Ruas Jalan Raya Pantura Tuban-Widang KM 0,00- KM 29,00 pada tahun 2015-2018. Karakteristik kecelakaan yang ditinjau adalah jumlah kejadian, kendaraan yang telibat, tingkat keparahan korban, waktu ke- 
jadian, usia dan jenis kelamin, tipe tabrakan, dan faktor-faktor penyebab kecelakaan.

Penentuan lokasi blackspot dilakukan dengan mengggunakan metode accident rate (tingkat kecelakaan dan tingkat fatalitas), Angka Ekivalen Kecelakaan (AEK), dan metode cussum (cumulative summary).

Analisis data kecepatan menggunakan metode 85 persentil yaitu kecepatan 85\% kendaraan dan dibawahnya untuk dapat mewakili besarnya kecepatan dilapangan pada lokasi blackspot. Setelah didapatkan data kecepatan dilapangan kemudian dilakukan pengujian hipotesis dengan Uji Z untuk mengetahui apakan kecepatan kendaraan pada lokasi blackspot melebihi batas kecepatan maksimun. Hubungan antara kecepatan dengan kecelakaan dilakukan dengan uji korelasi dan regresi untuk mendapatkan hubungan keeratan dan persamaan yang terbaik yang dapat mewakili kondisi lapangan. Pengumpulan data dilakukan dengan cara sebagai berikut:

1. Pengambilan data kecelakaan dari Satlantas Polres Tuban. Data kecelakaan berisi lo kasi, waktu, kondisi korban akibat kecelakaan, tipe/jenis tabrakan, dan faktor penyebab kecelakaan.

2. Survei lapangan untuk mengetahui kondisi lapangan atau tataguna lahan pada ruas jalan yang ditinjau. Selain itu juga untuk mendapatkan data volume lalu lintas kenda raan dan kecepatan kendaraan pada lokasi blackspot.

\section{HASIL}

\subsection{Analisis Kecelakaan Berdasarkan Karakteristik}

Karakteristik kecelakaan dibagi menjadi beberapa jenis yaitu tahun kejadian, kendaraan yang terlibat, tingkat keparahan korban, waktu, Usia dan jenis kelamin, tipe tabrakan dan faktor penyebab.

1. Analisis Kejadian Kecelakaan berdasarkan karakteristiknya

Tabel 1 Karakteristik Kecelakaan pada Ruas Jalan Raya Pantura Tuban-Widang KM 0,00KM 29,00

\begin{tabular}{cccccccc}
\hline NO & \multicolumn{1}{c}{ Jenis } & Satuan & $\mathbf{2 0 1 4}$ & $\mathbf{2 0 1 5}$ & $\mathbf{2 0 1 6}$ & $\mathbf{2 0 1 7}$ & Total \\
\hline 1 & Kejadian Kecelakaan & kejadian & 117 & 159 & 111 & 122 & 509 \\
\hline 2 & Kendaraan yang Terlibat & & & & & & \\
& Pejalan Kaki & Orang & 8 & 6 & 11 & 8 & 33 \\
& Roda 2 & Unit & 130 & 170 & 116 & 125 & 541 \\
& Roda 4 & Unit & 91 & 125 & 94 & 99 & 409 \\
\hline 3 & Korban Kecelakaan & & & & & & \\
& Korban Meninggal Dunia & Orang & 23 & 24 & 23 & 41 & 111 \\
& Korban Luka Berat & Orang & 15 & 3 & 8 & 7 & 33 \\
& Korban Luka Ringan & Orang & 143 & 219 & 146 & 136 & 644 \\
& Total Korban & Orang & 181 & 246 & 177 & 184 & 788 \\
\hline 4 & Waktu Kecelakaan & & & & & & \\
& Kecelakaan pada Pagi Hari & kejadian & 39 & 52 & 38 & 35 & 164 \\
& Kecelakaan pada Siang Hari & kejadian & 31 & 43 & 31 & 35 & 140 \\
& Kecelakaan pada Malam Hari & kejadian & 29 & 38 & 25 & 27 & 119 \\
& Kecelakaan pada Dini Hari & kejadian & 18 & 26 & 17 & 25 & 86 \\
\hline
\end{tabular}


2. Analisis kejadian kecelakaan berdasarkan waktu kejadian

Tabel 2. Hari Terjadinya Kecelakaan pada Ruas Jalan Raya Pantura Tuban-Widang KM 0,00KM 29,00

\begin{tabular}{|c|c|c|c|c|c|c|}
\hline \multirow{2}{*}{$\begin{array}{c}\text { Parameter } \\
\text { (Hari) }\end{array}$} & \multicolumn{4}{|c|}{ Tahun Terjadinya Kecelakaan } & \multirow{2}{*}{$\Sigma$} & \multirow{2}{*}{$\begin{array}{c}\text { Persentase } \\
(\%)\end{array}$} \\
\hline & 2015 & 2016 & 2017 & 2018 & & \\
\hline Senin & 15 & 27 & 12 & 17 & 71 & 13.95 \\
\hline Selasa & 14 & 22 & 15 & 17 & 68 & 13.36 \\
\hline Rabu & 11 & 23 & 19 & 20 & 73 & 14.34 \\
\hline Kamis & 23 & 21 & 16 & 19 & 79 & 15.52 \\
\hline Jum'at & 13 & 28 & 20 & 8 & 69 & 13.56 \\
\hline Sabtu & 20 & 16 & 17 & 23 & 76 & 14.93 \\
\hline Minggu & 21 & 22 & 12 & 18 & 73 & 14.34 \\
\hline
\end{tabular}

3. Analisis kejadian kecelakaan berdasarkan usia dan jenis kelamin

Tabel 3. Usia Pelaku Kecelakaa pada Ruas Jalan Raya Pantura Tuban-Widang KM 0,00- KM 29,00

\begin{tabular}{|c|c|c|c|c|c|c|}
\hline \multirow{2}{*}{ Usia (th) } & \multicolumn{4}{|c|}{ Tahun Terjadinya Kecelakaan } & \multirow{2}{*}{$\Sigma$} & \multirow{2}{*}{$\begin{array}{c}\text { Persen } \\
(\%)\end{array}$} \\
\hline & 2015 & 2016 & 2017 & 2018 & & \\
\hline $0-9$ th & 0 & 2 & 1 & 0 & 3 & 0.38 \\
\hline $10-15$ th & 10 & 9 & 12 & 0 & 31 & 3.93 \\
\hline $15-30$ th & 82 & 105 & 98 & 99 & 384 & 48.73 \\
\hline $31-40$ th & 55 & 87 & 37 & 65 & 244 & 30.96 \\
\hline $41-50$ th & 29 & 31 & 28 & 20 & 108 & 13.71 \\
\hline 51 tahun keatas & 5 & 12 & 1 & 0 & 18 & 2.28 \\
\hline
\end{tabular}

Tabel 4. Jenis Kelamin Pelaku Kecelakaan pada Ruas Jalan Raya Pantura Tuban-Widang KM $0,00-$ KM 29,00

\begin{tabular}{llllllll}
\hline \multirow{2}{*}{ Jenis Kelamin } & \multicolumn{9}{c}{ Tahun Terjadinya Kecelakaan } & \multirow{2}{*}{ P } & \multirow{2}{*}{ Persen (\%) } \\
\cline { 2 - 5 } & $\mathbf{2 0 1 5}$ & $\mathbf{2 0 1 6}$ & $\mathbf{2 0 1 7}$ & $\mathbf{2 0 1 8}$ & & \\
\hline Laki-laki (L) & 141 & 184 & 118 & 140 & 583 & 73.98 \\
\hline Perempuan (P) & 40 & 62 & 59 & 44 & 205 & 26.02 \\
\hline
\end{tabular}

4. Analisis kejadian kecelakaan berdasarkan tipe tabrakan

Tabel 5. Tipe/Jenis Tabrakan Pada Ruas Jalan Raya Pantura Tuban-Widang KM 0,00 - KM 29,00

\begin{tabular}{|c|c|c|c|c|c|c|}
\hline \multirow{2}{*}{ Tipe Kecelakaan } & \multicolumn{4}{|c|}{ Tahun Terjadinya Kecelakaan } & \multirow{2}{*}{$\Sigma$} & \multirow{2}{*}{$\begin{array}{c}\text { Persentase } \\
(\%)\end{array}$} \\
\hline & 2015 & 2016 & 2017 & 2018 & & \\
\hline Depan - Samping & 39 & 38 & 34 & 41 & 152 & 28.68 \\
\hline Depan -Belakang & 31 & 40 & 21 & 23 & 115 & 21.7 \\
\hline Depan - Depan & 16 & 14 & 15 & 10 & 55 & 10.38 \\
\hline Pejalan Kaki & 9 & 6 & 15 & 10 & 40 & 7.55 \\
\hline Samping -Samping & 17 & 9 & 24 & 23 & 73 & 13.77 \\
\hline Laka Tunggal & 5 & 23 & 2 & 17 & 47 & 8.87 \\
\hline Tabrak Lari & & 28 & & 15 & 43 & 8.11 \\
\hline Penumpang Jatuh & & 3 & & & 3 & 0.57 \\
\hline Lain-lain & & 2 & & & 2 & 0.38 \\
\hline
\end{tabular}


5. Analisis kejadian kecelakaan berdasarkan faktor penyebab kecelakaan

Tabel 6 Faktor Penyebab Kecelakaan Pada Ruas Jalan Raya Pantura Tuban-Widang KM $0,00-$ KM 29,00

\begin{tabular}{clllllll}
\hline No & Faktor Penyebab Kecelakaan & $\mathbf{2 0 1 5}$ & $\mathbf{2 0 1 6}$ & $\mathbf{2 0 1 7}$ & $\mathbf{2 0 1 8}$ & Total & Persentase \\
\hline 1 & Faktor Alam & 4 & 12 & 5 & 0 & 21 & $0.68 \%$ \\
\hline 2 & Faktor Jalan & 57 & 90 & 16 & 26 & 189 & $6.08 \%$ \\
\hline 3 & Faktor Kendaraan & 11 & 12 & 15 & 14 & 52 & $1.67 \%$ \\
\hline 4 & Faktor Pengemudi & 442 & 867 & 782 & 753 & 2844 & $91.56 \%$ \\
\hline
\end{tabular}

\subsection{Pengolahan Data Lalu lintas}

Dari hasil survei volume kendaraan maka perlu dikalikan dengan faktor ekivalensi mobil penumpang (EMP) agar memiliki kedudukan yang sama untuk sertiap golongan kendaraan yang memiliki ukuran yang berbeda-beda.

Berikut ini contoh perhitungan volume kendaraan pada jam puncak Ruas Jalan Raya Pantura Tuban-Widang KM 0,00- KM 29,00 Segmen 1

$$
\begin{aligned}
& \text { Waktu } \quad=07.00-08.00 \mathrm{WIB} \\
& \text { Jumlah Kendaraan MC } \quad=1515 \mathrm{kend} / \mathrm{jam} \\
& \text { Jumlah Kendaaan LV } \quad=402 \mathrm{kend} / \mathrm{jam} \\
& \text { Jumlah Kendaraan MHV = } \quad=188 \mathrm{kend} / \mathrm{jam} \\
& \text { Jumlah Kendaraan LT = } \quad 261 \mathrm{kend} / \mathrm{jam} \\
& \text { Jumlah Kendaraan LB } \quad=5 \mathrm{kend} / \mathrm{jam} \\
& \text { Jumlah Kendaraan UM = } 40 \text { kend } / \text { jam } \\
& \mathrm{Q}=(\mathrm{MCx} 0.5)+(\mathrm{LVx} 1)+(\mathrm{HVx} 1.3)+(\mathrm{LTx} 2.5)+(\mathrm{LBx} 1.5)+(\mathrm{UMx} 1) \\
& =(1515 \times 0.5)+(402 \times 1)+(188 \times 1.3)+(261 \times 2.5)+(5 \times 1.5)+(40 \times 1) \\
& =2103,9 \mathrm{smp} / \mathrm{jam}
\end{aligned}
$$

Setelah didapatkan volume jam puncak tahun 2020, kemudian mengubah data volume lalu lintas pada jam puncak menjadi lalu lintas harian rata-rata per tahun (LHRt)

$$
\text { LHRt }=\frac{\text { VolumeJamPuncak }}{k}=\frac{2103,9}{0,11}=19127 \mathrm{smp}
$$

Dengan nilai seperti diatas dilakukan pada setiap segmen sehingga didapatkan nilai LHRt yang digunakan untuk perhitungan accident rate

Tabel 7 LHRt Jalan Raya Pantura Tuban-Widang KM 0,00- KM 29,00

\begin{tabular}{ccccc}
\hline Segmen & Station & Hari & QDH (smp/jam) & LHRt (smp) \\
\hline \multirow{2}{*}{1} & \multirow{2}{*}{ STA 91+000-97+000 } & Minggu & 2103.9 & 19127 \\
& & Senin & 2418 & 21982 \\
2 & \multirow{2}{*}{ STA 84+000-91+000 } & Minggu & 1999.3 & 18176 \\
& & Senin & 1998.8 & 18171 \\
\multirow{2}{*}{3} & \multirow{2}{*}{ STA 79+000-84+000 } & Minggu & 2092.9 & 19027 \\
& & Senin & 1309 & 11900 \\
\multirow{2}{*}{4} & \multirow{2}{*}{ STA 73+000-79+000 } & Minggu & 1659.6 & 15088 \\
& & Senin & 1220.6 & 11097 \\
\multirow{2}{*}{5} & \multirow{2}{*}{ STA 68+000-73+000 } & Minggu & 2058.6 & 18715 \\
& & Senin & 1515.8 & 13780 \\
\hline
\end{tabular}




\section{Penentuan lokasi daerah rawan kecelakaan (blackspot)}

\section{Tingkat Kecelakaan}

Dalam menentukan lokasi blackspot salah satu metode yang digunakan adalah perhi tungan tingkat kecelakaan (TK) dengan satuan 100 JPKP.

Berikut merupakan contoh perhitungan untuk STA 95+00-96+000

$$
T k=\frac{\text { JumlahKecelakaanx } 10^{8}}{\text { LHRtxnxLx365 }}
$$

Jumlah kejadian $(\mathrm{Fk})=8$ kejadian (selama 4 tahun)

$\begin{array}{ll}\text { Panjang } & =1000 \text { meter } \\ \text { LHRt } & =21982 \mathrm{smp}\end{array}$

$T K=\frac{8 \times 10^{8}}{21982 \times 4 \times 1 \times 365}=24,93$ kejadian kecelakaan $(100 \mathrm{JPKP})$

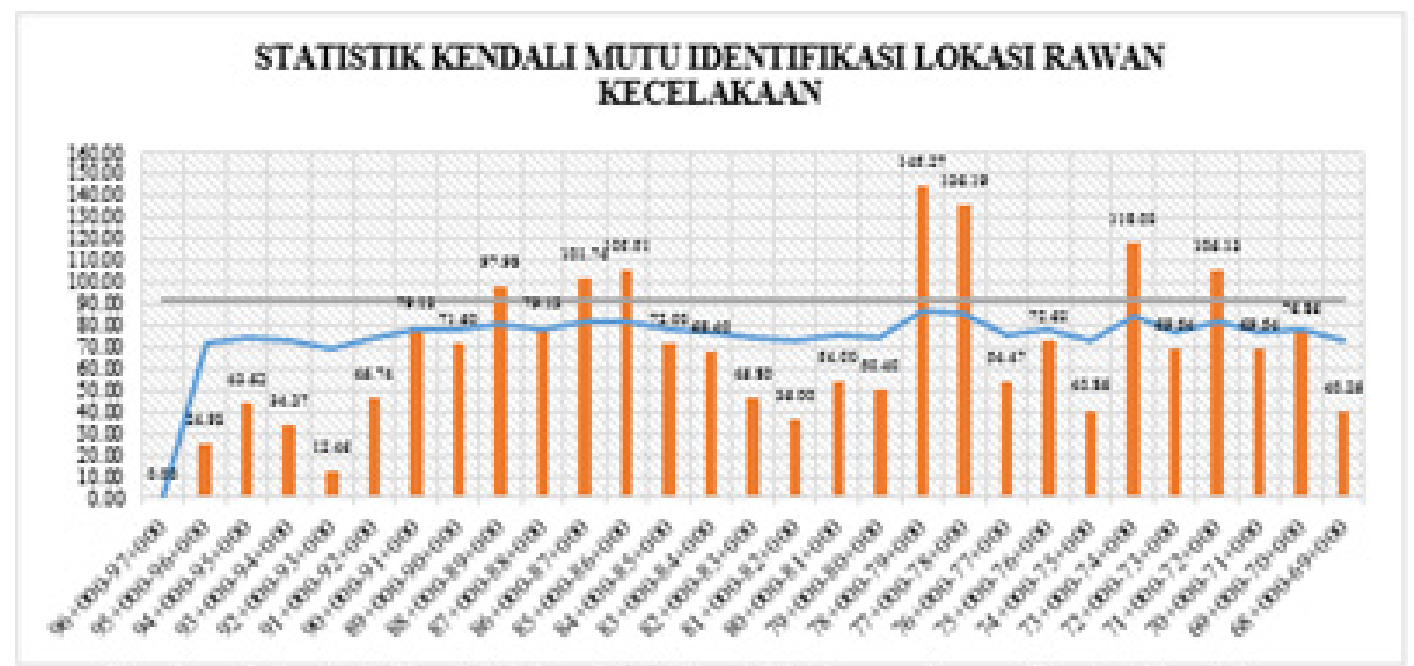

Gambar_l Statistik Kendali Mutu Identifikasi Black spot dengan Tinglat Kecelakaan

2. Tingkat Fatalitas

Dalam menentukan lokasi blackspot salah satu metode yang digunakan adalah perhi tungan tingkat fatalitas (Tf) dengan satuan $100 \mathrm{JPKP}$.

Berikut merupakan contoh perhitungan untuk STA 94+00-95+000

$$
T f=\frac{\text { Jumlahkejadian } x 10^{8}}{\text { LHRtxnxLx365 }}
$$

Jumlah kejadian (Fkm) $\quad=2$ kejadian (selama 4 tahun)

Panjang

$=1000$ meter

LHRt

$$
=21982 \mathrm{smp}
$$

$T K=\frac{2 \times 10^{8}}{21982 \times 4 \times 1 \times 365}=6,23$ Kematian $(100 \mathrm{JPKP})$ 


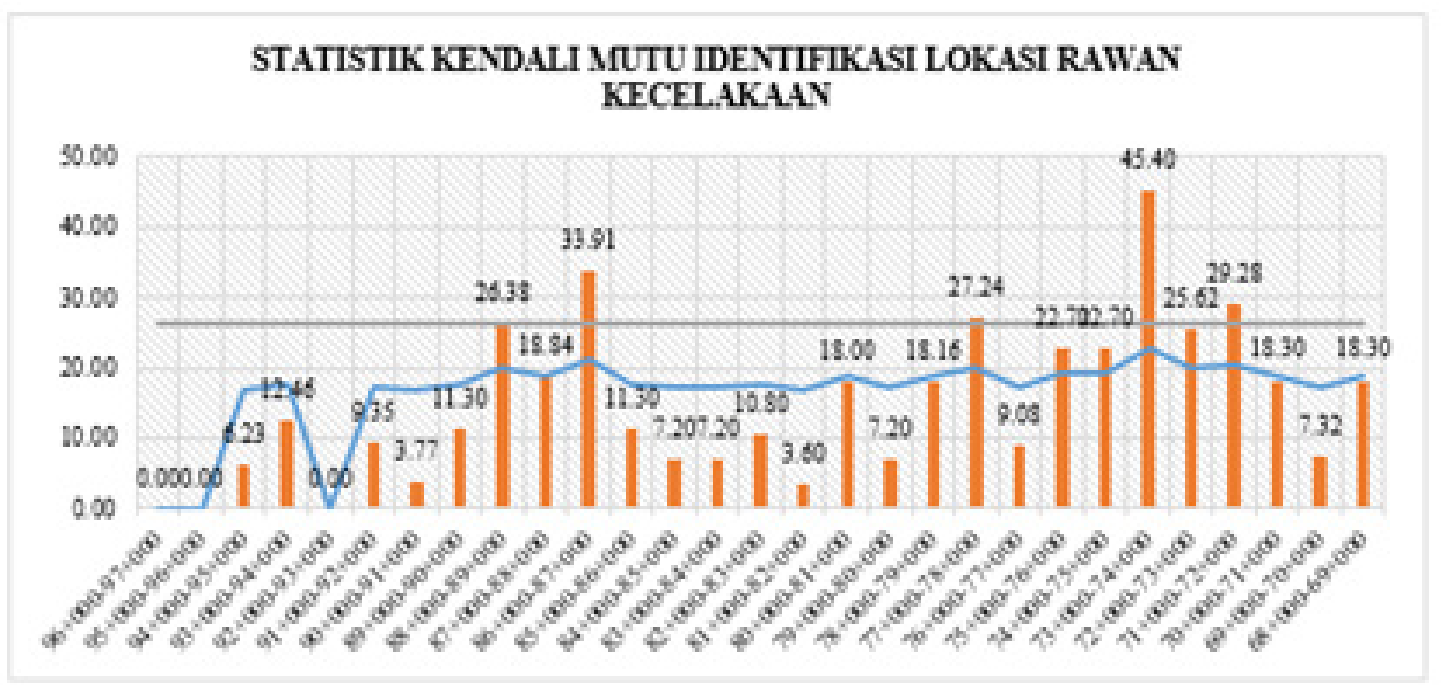

Gambar 2 Statistik Kendali Mutu Identifikasi Black spot dengan Tingkat Fatalitas

\section{Angka Ekivalen Kecelakaan}

Dalam menentukan lokasi blackspot salah satu metode yang digunakan adalah meng hitung angka ekivalen kecelakaan (AEK) per 1000 meter

Berikut merupakan contoh perhitungan untuk STA 95+000-96+000

$$
\begin{aligned}
\mathrm{AEK} & =12 \mathrm{MD}+3 \mathrm{LB}+3 \mathrm{LR} \\
& =12(0)+3(0)+3(12) \\
& =36
\end{aligned}
$$

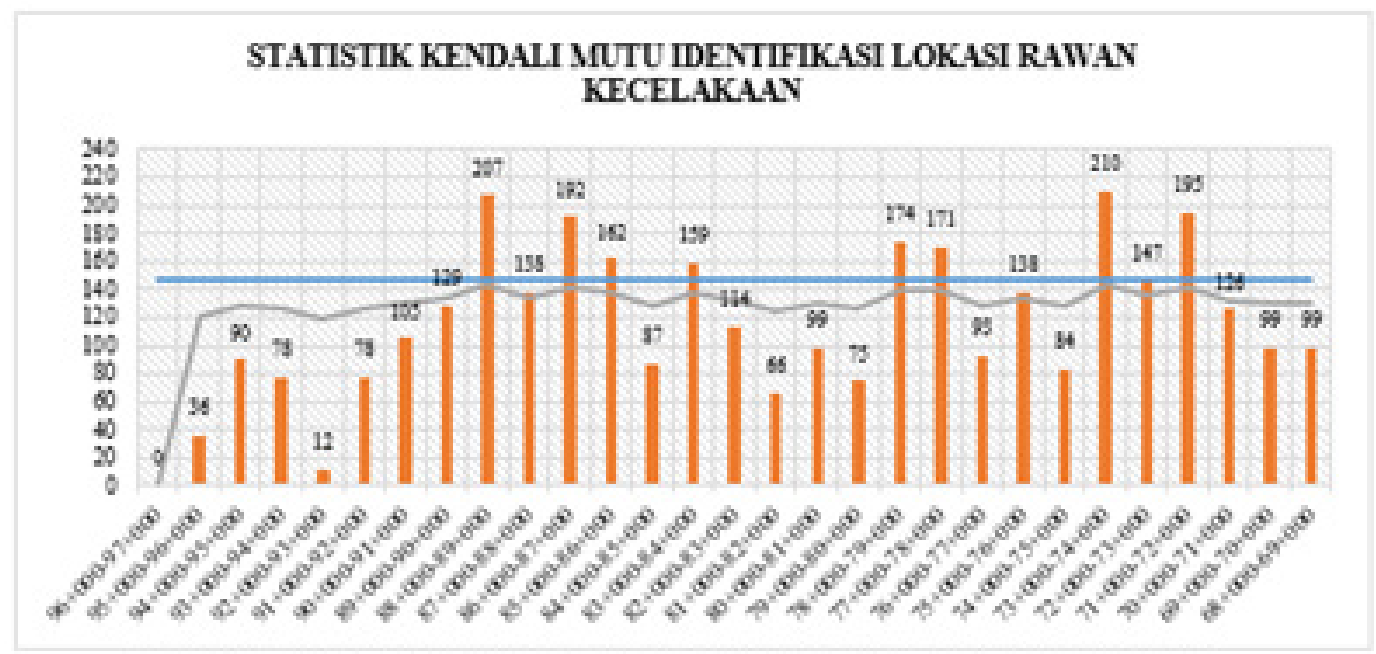

Gambar. 3 Statistik Kendali Mutu Identifikasi Black spot dengan AEK

\section{Metode Cummulative summary}

Untuk menentukan lokasi blackspot salah satu metode yang dilakukan adalah perhi tungan nilai cussum PerSTA.

Perhitungan nilai cussum untuk tahun pertama

$\mathrm{S} 0=(\mathrm{Xi}-\mathrm{W})$ 
Perhitungan nilai cussum tahun berikutnya

$\mathrm{S} 1=[\mathrm{S} 0+(\mathrm{Xi}-\mathrm{W})]$

Keterangan : S0 adalah nilai cussum kecelakaan tahun pertama

$\mathrm{Xi}$ adalah jumlah kecelakaan pada tahun ke-i

$\mathrm{W}$ adalah nilai mean

Berikut contoh perhitungan nilai cussum STA 95+000-96+000

Jumlah kejadian : : Tahun 2015 : 1 kejadian

Tahun 2016 : 5 kejadian

Tahun $2017: 1$ kejadian

Tahun $2018: 1$ kejadian

Nilai meas $=4,39$ kejadian

Nilai Cussum S2015

$$
=1-4,39
$$$$
=-3,39
$$

S2015

$=-3,39+(5-4,39)$

$=-2,78$

S2015

$=-2,79+(1-4,29)$

$=-6,16$

S2015

$=-6,16+(1-4,39)$

$=-9,55$

Perhitungan diatas didapatkan nilai cussum pada Jalan Raya Pantura Tuban-Widang KM 0,00- KM 29,00 pada STA 95+000-96+000 adalah -9,55.

Perhitungan seperti tersebut dilakukan per 1000 m sepanjang Jalan Raya Pantura Tuban-Widang KM 0,00- KM 29,00 sepanjang 29 km kemudian nantinya diambil nilai tertinggi berdasarkan interval persyaratan nilai. Berdasarkan perhitungan menggunakan nilai cussum didapatkan tujuh titik yang menjadi lokasi rawan kecelakaan yaitu STA $88+000-89+000$, STA $86+000-87+000$, STA $85+000-86+000$, STA 78+000$79+000$, STA $77+000-78+000$, STA $73+000-74+000$, dan STA $71+000-72+000$

\section{Hubungan antara kecepatan dengan kecelakaan}

1. Pengujian Hipotesis Kecepatan 85 persentil dengan Batas Maksimum Kecepatan Jalan Arteri.

Tabel 8 Hipotesis Pengujian Kecepatan pada lokasi blackspot

\begin{tabular}{|c|c|c|c|c|c|}
\hline $\begin{array}{l}\text { Stationing } \\
\text { (STA) }\end{array}$ & Jenis kendaraan & $\begin{array}{c}\text { Persen- } \\
\text { til-85 (km/ } \\
\text { jam) }\end{array}$ & $\mathbf{Z 0}$ & KET & Kesimpulan \\
\hline \multirow{3}{*}{$\begin{array}{l}\text { STA } 88+000- \\
\quad 89+000\end{array}$} & Kendaraan Berat (HV) & 59.5 & -15.2 & $Z_{0}<Z \alpha$ & $\begin{array}{c}\text { Tolak H0 Vkend < } \\
\text { Vreg }\end{array}$ \\
\hline & $\begin{array}{l}\text { Kendaraan Ringan } \\
\text { (LV) }\end{array}$ & 61.29 & -10.61 & $\mathrm{Z}_{\mathrm{o}}<\mathrm{Z} \alpha$ & $\begin{array}{c}\text { Tolak H0 Vkend }< \\
\text { Vreg }\end{array}$ \\
\hline & Sepeda Motor (MC) & 88.5 & 4.48 & $\mathrm{Z}_{\mathrm{o}}>\mathrm{Z} \alpha$ & $\begin{array}{c}\text { Terima H0 Vkend > } \\
\text { Vreg }\end{array}$ \\
\hline \multirow{3}{*}{$\begin{array}{l}\text { STA } 86+000- \\
\quad 87+000\end{array}$} & Kendaraan Berat (HV) & 51.67 & -19.12 & $\mathrm{Z}_{\mathrm{o}}<\mathrm{Z} \alpha$ & $\begin{array}{c}\text { Tolak H0 Vkend }< \\
\text { Vreg }\end{array}$ \\
\hline & $\begin{array}{l}\text { Kendaraan Ringan } \\
\text { (LV) }\end{array}$ & 82.31 & 1.46 & $\mathrm{Z}_{\mathrm{o}}>\mathrm{Z} \alpha$ & $\begin{array}{c}\text { Terima H0 Vkend }> \\
\text { Vreg }\end{array}$ \\
\hline & Sepeda Motor (MC) & 85.44 & 3.13 & $\mathrm{Z}_{\mathrm{o}}>\mathrm{Z} \alpha$ & $\begin{array}{c}\text { Terima H0 Vkend > } \\
\text { Vreg }\end{array}$ \\
\hline \multirow{3}{*}{$\begin{array}{l}\text { STA } 85+000- \\
\quad 86+000\end{array}$} & Kendaraan Berat (HV) & 61 & -12.2 & $\mathrm{Z}_{\mathrm{o}}<\mathrm{Z} \alpha$ & $\begin{array}{c}\text { Tolak H0 Vkend < } \\
\text { Vreg }\end{array}$ \\
\hline & $\begin{array}{l}\text { Kendaraan Ringan } \\
\text { (LV) }\end{array}$ & 80.55 & 0.35 & $\mathrm{Z}_{\mathrm{o}}>\mathrm{Z} \alpha$ & $\begin{array}{c}\text { Terima H0 Vkend }> \\
\text { Vreg }\end{array}$ \\
\hline & Sepeda Motor (MC) & 81.8 & 1.13 & $Z_{0}>Z \alpha$ & $\begin{array}{c}\text { Terima H0 Vkend }> \\
\text { Vreg }\end{array}$ \\
\hline
\end{tabular}


Lanjutan Tabel 8 Hipotesis Pengujian Kecepatan pada lokasi blackspot

\begin{tabular}{|c|c|c|c|c|c|}
\hline $\begin{array}{l}\text { Stationing } \\
\text { (STA) }\end{array}$ & Jenis kendaraan & $\begin{array}{c}\text { Persentil-85 } \\
(\mathrm{km} / \mathrm{jam})\end{array}$ & $\mathbf{Z 0}$ & KET & Kesimpulan \\
\hline \multirow[t]{3}{*}{$\begin{array}{l}\text { STA } 83+000- \\
84+000\end{array}$} & $\begin{array}{l}\text { Kendaraan Berat } \\
(\mathrm{HV})\end{array}$ & 69.92 & -6.47 & $\mathrm{Z}_{\mathrm{o}}<\mathrm{Z} \alpha$ & $\begin{array}{l}\text { Tolak H0 Vkend }< \\
\text { Vreg }\end{array}$ \\
\hline & $\begin{array}{l}\text { Kendaraan } \\
\text { Ringan (LV) }\end{array}$ & 91.53 & 6.24 & $\mathrm{Z}_{0}>\mathrm{Z} \alpha$ & $\begin{array}{l}\text { Terima H0 Vkend > } \\
\text { Vreg }\end{array}$ \\
\hline & $\begin{array}{l}\text { Sepeda Motor } \\
\text { (MC) }\end{array}$ & 91.3 & 6.67 & $\mathrm{Z}_{0}>\mathrm{Z} \alpha$ & $\begin{array}{l}\text { Terima H0 Vkend > } \\
\text { Vreg }\end{array}$ \\
\hline \multirow[t]{3}{*}{$\begin{array}{l}\text { STA 78+000- } \\
79+000\end{array}$} & $\begin{array}{l}\text { Kendaraan Berat } \\
(\mathrm{HV})\end{array}$ & 88.9 & 4.77 & $\mathrm{Z}_{0}>\mathrm{Z} \alpha$ & $\begin{array}{l}\text { Terima H0 Vkend > } \\
\text { Vreg }\end{array}$ \\
\hline & $\begin{array}{l}\text { Kendaraan } \\
\text { Ringan (LV) }\end{array}$ & 98.59 & 10.51 & $\mathrm{Z}_{0}>\mathrm{Z} \alpha$ & $\begin{array}{l}\text { Terima H0 Vkend > } \\
\text { Vreg }\end{array}$ \\
\hline & $\begin{array}{l}\text { Sepeda Motor } \\
(\mathrm{MC})\end{array}$ & 91.41 & 5.69 & $\mathrm{Z}_{0}>\mathrm{Z} \alpha$ & $\begin{array}{l}\text { Terima H0 Vkend > } \\
\text { Vreg }\end{array}$ \\
\hline \multirow[t]{3}{*}{$\begin{array}{l}\text { STA } 77+000- \\
78+000\end{array}$} & $\begin{array}{l}\text { Kendaraan Berat } \\
\text { (HV) }\end{array}$ & 81.78 & 0.87 & $\mathrm{Z}_{0}>\mathrm{Z} \alpha$ & $\begin{array}{l}\text { Terima H0 Vkend > } \\
\text { Vreg }\end{array}$ \\
\hline & $\begin{array}{l}\text { Kendaraan } \\
\text { Ringan (LV) }\end{array}$ & 98.05 & 10.75 & $\mathrm{Z}_{0}>\mathrm{Z} \alpha$ & $\begin{array}{l}\text { Terima H0 Vkend > } \\
\text { Vreg }\end{array}$ \\
\hline & $\begin{array}{l}\text { Sepeda Motor } \\
\text { (MC) }\end{array}$ & 97.83 & 9.58 & $\mathrm{Z}_{0}>\mathrm{Z} \alpha$ & $\begin{array}{l}\text { Terima H0 Vkend > } \\
\text { Vreg }\end{array}$ \\
\hline \multirow[t]{3}{*}{$\begin{array}{l}\text { STA 73+000- } \\
74+000\end{array}$} & $\begin{array}{l}\text { Kendaraan Berat } \\
(\mathrm{HV})\end{array}$ & 70.06 & -5.23 & $\mathrm{Z}_{0}<\mathrm{Z} \alpha$ & $\begin{array}{l}\text { Tolak H0 Vkend < } \\
\text { Vreg }\end{array}$ \\
\hline & $\begin{array}{l}\text { Kendaraan } \\
\text { Ringan (LV) }\end{array}$ & 97.31 & 8.49 & $\mathrm{Z}_{0}>\mathrm{Z} \alpha$ & $\begin{array}{l}\text { Terima H0 Vkend } \\
\text { >Vreg }\end{array}$ \\
\hline & $\begin{array}{l}\text { Sepeda Motor } \\
\text { (MC) }\end{array}$ & 71.87 & -4.14 & $\mathrm{Z}_{0}<\mathrm{Z} \alpha$ & $\begin{array}{l}\text { Tolak H0 Vkend < } \\
\text { Vreg }\end{array}$ \\
\hline \multirow[t]{3}{*}{$\begin{array}{l}\text { STA } 71+000- \\
72+000\end{array}$} & $\begin{array}{l}\text { Kendaraan Berat } \\
(\mathrm{HV})\end{array}$ & 69.5 & -6.2 & $\mathrm{Z}_{0}<\mathrm{Z} \alpha$ & $\begin{array}{l}\text { Tolak H0 Vkend < } \\
\text { Vreg }\end{array}$ \\
\hline & $\begin{array}{l}\text { Kendaraan } \\
\text { Ringan (LV) }\end{array}$ & 70.93 & -4.84 & $\mathrm{Z}_{0}<\mathrm{Z} \alpha$ & $\begin{array}{l}\text { Tolak H0 Vkend < } \\
\text { Vreg }\end{array}$ \\
\hline & $\begin{array}{l}\text { Sepeda Motor } \\
(\mathrm{MC})\end{array}$ & 70.93 & -5.09 & $\mathrm{Z}_{0}<\mathrm{Z} \alpha$ & $\begin{array}{l}\text { Tolak H0 Vkend < } \\
\text { Vreg }\end{array}$ \\
\hline
\end{tabular}

2. Hubungan Antara Kecepatan dengan Kecelakaan pada Kendaraan Sepeda Motor

Tabel 9 Uji Korelasi dan Regresi Untuk Kendaraan Sepeda Motor

\begin{tabular}{|c|c|c|c|}
\hline \multirow{2}{*}{ Jenis Regresi } & \multicolumn{3}{|c|}{ MC (Sepeda Motor) } \\
\hline & $\mathbf{r}$ & $\mathbf{R}^{2}$ & Persamaan Matematis \\
\hline Linear & $0.60 \leq 0.789 \leq 0.80$ & 0.622 & $-7.146+1.70 x$ \\
\hline Polynomial & $0.60 \leq 0.789 \leq 0.80$ & 0.623 & $-3.458+0.080 x+0.001 x^{2}$ \\
\hline Polynomial orde 3 & $0.80 \leq 0.839 \leq 1.00$ & 0.705 & $-817.61+29.294 x-0.3462 x^{2}+0.001 x^{3}$ \\
\hline Eksponensial & $0.60 \leq 0.747 \leq 0.80$ & 0.558 & $0,618 \mathrm{e} 0.028 \mathrm{x}$ \\
\hline Logaritma & $0.60 \leq 0.788 \leq 0.80$ & 0.621 & $54.723+1.97 \ln (x)$ \\
\hline
\end{tabular}


3. Hubungan Antara Kecepatan dengan Kecelakaan pada Kendaraan Ringan

Tabel 10 Uji Korelasi dan Regresi Untuk Kendaraan Ringan

\begin{tabular}{lccl}
\hline \multirow{2}{*}{ Jenis Regresi } & \multicolumn{3}{c}{ LV (Kendaraan Ringan) } \\
& \multicolumn{1}{c}{$\mathbf{r}$} & $\mathbf{R}^{\mathbf{2}}$ & \multicolumn{1}{c}{ Persamaan Matematis } \\
\hline Linear & $0.40 \leq 0.56 \leq 0.60$ & 0.314 & $-1.723+0.048 \mathrm{x}$ \\
Polynomial & $0.60 \leq 0.646 \leq 0.80$ & 0.417 & $14.874-0.371 \mathrm{x}+0.003 \mathrm{x}^{2}$ \\
Polynomial orde 3 & $0.60 \leq 0.659 \leq 0.80$ & 0.435 & $80.977-2.924 \mathrm{x}+0.0349 \mathrm{x}^{2}-0.0001 \mathrm{x}^{3}$ \\
Eksponensial & $0.60 \leq 0.605 \leq 0.80$ & 0.366 & $0.400 \mathrm{e} 0.020 \mathrm{x}$ \\
Logaritma & $0.40 \leq 0.536 \leq 0.60$ & 0.288 & $-13.975+3.690 \ln (\mathrm{x})$ \\
\hline
\end{tabular}

4. Hubungan Antara Kecepatan dengan Kecelakaan pada Kendaraan Ringan

Tabel 11 Uji Korelasi dan Regresi Untuk Kendaran Berat

\begin{tabular}{lcll}
\hline \multirow{2}{*}{ Jenis Regresi } & \multicolumn{2}{c}{ HV (Kendaraan Berat) } \\
& \multicolumn{1}{c}{$\mathbf{r}$} & \multicolumn{1}{c}{$\mathbf{R}^{2}$} & \multicolumn{1}{c}{ Persamaan Matematis } \\
\hline Linear & $0.40 \leq 0.505 \leq 0.60$ & 0.255 & $-1.940+0.111 \mathrm{x}$ \\
Polynomial & $0.40 \leq 0.507 \leq 0.60$ & 0.257 & $-6.473+0.243 \mathrm{x}-0.001 \mathrm{x}^{2}$ \\
Polynomial orde 3 & $0.60 \leq 0.611 \leq 0.80$ & 0.373 & $-233.89+10.374 \mathrm{x}-0.1485 \mathrm{x}^{2}-0.0007 \mathrm{x}^{3}$ \\
Eksponensial & $0.40 \leq 0.531 \leq 0.60$ & 0.282 & $1.151 \mathrm{e} 0.022 \mathrm{x}$ \\
Logaritma & $0.40 \leq 0.510 \leq 0.60$ & 0.26 & $-27.036+7.766 \ln (\mathrm{x})$ \\
\hline
\end{tabular}

\section{PEMBAHASAN}

Karakteristik Kecelakaan Lalu lintas

Kecelakaan lalu lintas merupakan suatu kejadian yang tak terduga dan dapat terjadi kapan saja dan dimana saja yang menelan banyak korban dan menyebabkan kerugian material maupun non material. Kecelakaan lalu lintas juga memiliki karakteristik yang diklasifikasikan berasarkan beberapa faktor yang terlibat didalamnya. 1. Tahun Terjadinya Kecelakaan

Berdasarkan data yang diperoleh dari Satlantas Polres Tuban, didapatkan bahwa kecelakaan terjadi selama 4 (empat) tahun pada ruas Jalan Raya Pantura Tuban-Widang KM 0.00-KM 29.00 tercacat terjadi 509 kejadian kecelakaan. Pada tahun 2015 tercatat sebanyak 117 kejadian kecalakaan, kemudian tahun 2016 mengalami peningkatan menjadi 159 kejadian kecalakaan. Selanjutnya pada tahun 2017 kembali mengalami penurunan yaitu 111 kejadian dan tahun 2018 terjadi peningkatan lagi dengan 122 kejadian. Naik turunya kejadian kecelakaan bisa disebabkan oleh beberapa faktor penyebab. 2. Kendaraan yang terlibat

Kendaraan yang terlibat dalam kecelakaan bervariasi seperti sepeda motor, kendaraan ringan (mobil, minibus, pick up), kendaraan berat (truck, bus besar), dan Pejalan kaki. Sepedah Motor memiliki persentase setengah dari total keseluruhan kendaraan yang terlibat yaitu sebesar 53,55\%. Kendraan ringan persentasenya 10,23\%, sedangkan untuk kendaraan berat memiliki persentase yang lumayan banyak yaitu 31,32\%. Sedangkan penjalan kaki menjadi faktor penyebab kecelakaan yang relatif kecil yaitu 4,91\% . Ban- 
yaknya kendaraan sepeda motor yang terlibat berbanding lurus dengan hasil survei volume lalu lintas yaitu kendaraan sepeda motor paling banyak yang lewati ruas jalan ini.

Kecelakaan yang disebabkan oleh sepeda motor merupakan akibat dari kesalahan mereka sendiri, hal itu dapat dilihat dari pengamatan dilapangan jika masih dijumpai pengguna penggendara sepeda motor yang melawan arus menggunakan telephon genggam saat berkendara,melaju dengan kecepatan tinggi, dan tidak taat akan peraturan berlalu lintas. Padahal Jalan Raya Pantura Tuban-Widang KM 0,00-KM 29,00 merupakan jalan dengan tingkat lalu lintas yang tinggi dan banyak kendaraan berat yang melintasi jalan tersebut. Sama halnya dalam penelitian Andini (2019), dikatakan bahwa sepeda motor merupakan kendaraan yang paling dominan terlibat kecekalaan pada jalan Yogyakarta-Bantul sebesar 75\%, hal ini disebabkan karena sepeda motor merupakan kendaraan roda dua yang kestabilitasnya mudah goyah dari pada kendaraan yang lain disamping itu juga pengguna sepeda motor banyak yang tidak mematuhi peraturan lalu lintas.

3. Tingkat Keparahan Korban

Menurut UU No 22 tentang Lalu Lintas Angkutan Jalan. Korban keceakaan lalu lintas terdiri dari 3 (tiga) kategori yaitu luka ringan, luka berat, dan meningal dunia. Berdasarkan Tabel 4.3 korban dengan luka ringan memiliki persentase paling dominan yaitu $81,78 \%$ dari total keseluruhan. Diurutan kedua yaitu, korban meninggal dunia dengan persentase $14,07 \%$ atau sebayak 112 korban dari total korban 796 . dan yang paling sedikit adalah korban dengan luka berat persentasenya $4,15 \%$ atau 33 korban. Luka ringan yang biasanya terjadi berupa lecet-lecet akibat goresan, memar, dan cedera ringan. Sesuai dengan Yandi (2020) menjelaskan bahwa kondisi korban kecelakaan yang terjadi pada jalan Yos Sudarso Palembang paling banyak adalah korban luka ringan 83 orang, kemudian luka berat 37 orang dan meninggal dunia 23 orang. 4. Waktu terjadinya kecelakaan

Waktu terjadinya kecelakaan dikelompokkan berdasarkan hari dan jam terjadinya baik pagi, siang maupun malam hari. berdasarkan hasil analisis kecelakaan sering terjadi pada hari kamis dengan persentase $15,52 \%$ atau sebanyak 79 . Tetapi jika dilihat dari keseluruhan hari terjadinya, kecelakaan pada ruas jalan raya Pantura Tuban-Widang KM 0,00- KM 29,00 dapat dikatakan relatif sama sehingga dapat disimpulkan jika setiap hari ruas jalan ini bisa berpotensi terjadi kecelakaan.

Sedangkan untuk Waktu yang paling sering terjadi kecelakaan yaitu pada pagi hari antara pukul >06.00-12.00 WIB. Dimana pagi hari merupakan waktu dimulainya aktivitas manusia mulai berangkat kesekolah, kepertokoan, kekantor, kepasar dan lain-lain akibatnya lalu lintas jalan menjadi padat. Disamping itu juga kebiasaan masyarakat yang tidak tepat waktu sehingga kecenderungan berkendara dengan kecepatan tinggi agar sampai tempat tujuan tepat waktu. Menurut Andini (2019) kecelakaan lalu lintas sering terjadi pada siang hari dengan rentang waktu 12.00-18.00 karena kondisi stamina tubuh yang menurun akibat kelelahan melakukan aktivitas di pagi hari. Tidak jauh berbeda dengan Herawati (2014) yang menyatakan bahwa kecelakaan paling banyak terjadi pada pukul 06.00-12.00 dan 12.00-18.00 karena pada dua jam tersebut merupakan jam puncak pagi, siang dan sore. 
Hal itu menunjukkan jika semakin padat lalu lintas jalan maka akan semakin banyak pula jumlah kecelakaan yang terjadi. Oleh karena itu pengguna jalan harus selalu berhati-hati.

\section{Usia Pelaku dan Jenis Kelamin}

Usia pelaku kecelakaan yang mendominasi kecelakaan adalah rentang 15-30 tahun dengan persentase 48,73\%. Hal ini dapat dikatakan jika kecelakaan didominasi oleh usia produktif yang saat ini banyak dihuni kaum milenial. Dimana mereka memiliki sifat agresif dan mencari jati diri dengan kecenderungan suka pamer akan kemampuannya (kebut-kebutan, memakai kendaraan yang tidak standar), sayangnya tidak dibarengi dengan kemampuan dan keahlian dalam berkendara yang baik. Berbeda dengan penelitian yang dilakukan oleh Andini (2019) pelaku kecelakaan terjadi pada rentang usia 41-60 tahun, hal ini karena usia tersebut memiliki kondisi fisik yang sudah melemah sehingga mengakibatkan menurunya konsentrasi dalam berkendara. Selain itu usia remaja juga menjadi pelaku terbesar dalam kecelakaan.

Jenis kelamin pelaku kecelakaan didominasi oleh Laki-laki yaitu sebanyak 583 orang dengan persentase $73,98 \%$. Hal ini karena pengguna kendaraan didominasi oleh laki-laki dari pada perempuan. Disamping itu juga laki-laki memiliki aktivitas yang berat karena sebagian besar merupakan kepala keluarga sehingga banyak beraktivitas diluar rumah. Wardhana (2016) menyebutkan jika penyebab utama kecelakaan pada Jl Thamrin-Jl Raya Mondoroko didominasi oleh pengendara dengan jenis kelamin laki-laki. Hal ini karena laki-laki memiliki kemampuan navigasi dan kemampuan mengemudi lebih baik dari perempuan sehingga kadang membuat mereka lenggah dan kurang waspada dalam berkendara. 6. Tipe tabrakan

Tipe tabrakan juga harus perlu diketahui untuk memepermudah menanganan kecelakaan lalu lintas. Tipe tabrakan yang sering terjadi pada ruas jalan ini yaitu tabrak depan-samping dengan persentase $28,86 \%$ atau sebanyak 152 kejadian. tipe tabrakan kedua yaitu tabrak depan-belakang dengan persentase 21,70\% atau sebayak 115 kejadian dan yang ketiga adalah tabrak depan-depan dengan persentase 10,38\% atau 55 kejadian. kecelakaan yang terjadi akibat tabrak depan-samping disebabkan karena kendaraan yang mau menyiap kurang antisipasi terhadap kendaraan didepanya. Hal ini dapat dilihat dari kondisi jalan dengan 2/2D (dua lajur dua arah tak terbagi median) sehingga perlu adanya kewaspadaan yang tinggi saat ingin menyalip kenadraan yang ada didepannya. Tipe tabrakan depan-samping juga sering dikategorikan bahwa kecelakaan sering terajadi pada persimpangan atau jalan yang lebih dari 1 lajur.

Hasil penelitian Aditriansyah (2018) menjelaskan jika kecelakaan yang lebih sering terjadi adalah pada posisi slide swipe dan rear end, hal ini terjadi akibat pengendara yang menyiap kendaraan yang tidak dalam posisi siap dan hati-hati sehingga saat berkendara dengan kecepatan tinggi pengemudi sering berhenti mendadak dan tentunya kendaraan dibelakang tidak siap apalagi tanpa memberikan sinyal terlebih dahulu. 7. Faktor penyebab Kecelakaan

Faktor penyebab kecelakaan lalu lintas yang pada ruas Jalan Raya Pantura TubanWidang KM 0,00-KM 29,00 dikelompokkan menjadi 4 (empat) kategori yaitu faktor 
alam, faktor jalan, faktor kendaraan, dan faktor pengemudi (manusia). Berdasarkan Tabel 4.8 faktor penyebab tertinggi adalah faktor pengemudi dengan persentase $91,57 \%$, kedua akibat faktor jalan sebesar 6,08\%, ketiga faktor kendaraan sebesar 1,67\%, dan keempat faktor alam sebesar $0,68 \%$. Faktor pengemudi atau manusia menjadi penyebab yang paling dominan diantara faktor-faktor yang lain, yaitu kecelakaan disebabkan karena lengah, lelah, mengantuk, kecepatan tinggi dan tidak mematuhi tata tertib berlalu lintas. Ke-lima penyebab tersebut merupakan kombinasi antara faktor fisiologi dan psikologi. Dimana pengendara sering tidak sabar untuk sampai tempat tujuan sehingga peraturanperaturan yang ada dijalan tidak diperhatikan. sehingga melaju dengan kecepatan tinggi.

\section{Mengidentifikasi Lokasi Daerah Rawan Kecelakaan (Blackspot)}

Berdasarkan Pedoman Penanganan lokasi rawan kecelakaan (2004), lokasi/daerah rawan kecelakaan adalah apabila ruas jalan tersebut memiliki angka kecelakaan yang tinggi, terjadi pada waktu yang relatif sama, lokasi kejadian yang menumpuk, dan memiliki faktor penyebab yang spesifik. Dalam hal ini pengolahan data kecelakaan ditentukan berdasarkan ruas per-kilometer. Metode yang digunakan metode tingkat kecelakaan, tingkat fatalitas, Angka Ekivalen Kecelakaan (AEK), dan metode Cummulative Summmary. Suatu ruas jalan dapat dikatakan rawan kecelakaan jika nilai perhitungan yang didapat lebih tinggi dari batas garis UCL(Upper Control limit) dan BKA (Batas kontrol Atas).

Dari perhitungan menggunakan rumus yang ditentukan pada sub bab 2.6 didapatkan 8 (delapan) titik lokasi daerah rawa kecelakaan yaitu pada STA $88+000-89+000$, STA 86+000$87+000$, STA $85+000-86+000$, STA $83+000-84+000$, STA 78+000-79+000, STA 77+00078+000, STA 73+000-74+000, dan STA 71+000-72+000. Pada penelitian Intari Dwi E, dkk (2019) penentuan lokasi blackspot menggunakan Angka Ekivalen Kecelakaan (AEK) dengan syarat nilain AEK lebih besar dari UCL. Dari hasil penelitian yang dilakukan didapatkan 1 segmen yang dianggap menjadi lokasi rawan kecelakaann dengan nilai AEK 429 $>275$,6. Sedangkan pada penelitian Fahza (2019) penentuan lokasi blackspot menggunakan Metode Cummulative summary yaitu lokasi rawan terletak pada STA 18-19 dan STA22-23.

Hubungan antara Kecepatan dengan Kecelakaan pada Lokasi Blackspot

1. Pengujian Hipotesis Kecepatan pada daerah rawan kecelakaan (Black spot)

faktor lain yang sering kali menjadi penyebab kecelakaan adalah faktor kecepatan kendaraan yang melintasi suatu ruas jalan. Perbedaaan kecepatan antara kendaraan yang satu dengan kendaraan yang lain sehingga salah satu kendaraan akan melanggar aturan batas kecepatan menjadi penyebab kecelakaan. Dari hasil perhitungan lokasi black spot Jalan Raya Pantura Tuban-Widang KM 0,00-KM 29,00 diperoleh 8 (delapan) titik yang dianggap sebagai zona rawan kecelakaan. Setelah itu dilakukan survei kecepatan pada titik-titik tersebut. Apakah kecepatan kendaraan yang melewati ruas jalan tersebut melebihi batas kecepatan yang ditentukan.

Dari hasil survei kecepatan yang sudah dianalisis didapatkan hasil untuk kendaraan sepeda motor rata-rata melaju dengan kecepatan diatas $80 \mathrm{~km} / \mathrm{jam}$. Hipote- 
sis menyatakan jika sepeda motor melebihi batas kecepatan dengan nilai Z0>Z $\alpha$. Untuk kendaraan ringan juga memiliki rata-rata kecepatan pada lokasi blackspot melebihi batas kecepatan, hipotesis menyatakan jika kendaraanringan melebihi batas kecepatan dengan nilai $\mathrm{Z} 0>\mathrm{Z} \alpha$. Sedangkan untuk kendaraan berat, ratarata melaju dengan dengan kecepatan dibawah $80 \mathrm{~km} / \mathrm{jam}$, yang artinya menolah hipotesis kecepatan pada kendaraan berat melebihi batas kecepatan dengan nilai $\mathrm{Z} 0<\mathrm{Z} \alpha$.

\section{Hubungan Korelasi dan Regresi antara kecepatan dengan kecelakaan pada lokasi blackspot.}

Berdasarkan hasil uji korelasi dan regresi linear pada kendaraan sepeda motor didapatkan nilai koefisien korelasi (r) sebesar 0,789 yang terletak pada interval $0.60 \leq \mathrm{r}$ $\leq 0.80$ dan koefisien determinan (R2) adalah 0.622 atau sama dengan 62,2\%. Angka tersebut mengandung arti bahwa jumlah kecelakaan dipengaruhi oleh kecepatan sebesar $62,2 \%$. Hasil persamaan regresi yaitu $y=-7,146+0.170 x$ yang artinya jika setiap penambahan kecepatan sebesar 1\% maka jumlah kecelakaan akan meningkat sebesar 0,170 . Sedangkan berdasarkan uji signifikansi didapatkan nilai sig $\alpha<0,05$ sehingga bisa diartikan jika terdapat pengaruh yang signifikansi antara kecepatan dengan kecelakaan pada sepeda motor. Model persamaaan yang dapat dijadikan acuan dalam menentukan hubungan antara kecepatan dan kecelakaan yaitu nilai koefisien korelasi harus besar atau mendekati 1 dan koefisien determinana diatas 60\%. Dari kelima model persamaan dipilih model polynomial orde 3 sebagai model persamaan terbaik untuk kendaraan sepeda motor yaitu dengan nilai $r=0.839$ dan $\mathrm{R} 2=0,705$ atau $70,5 \%$ dengan persamaan $\mathrm{Y}=-817,61+29,294 \mathrm{x}-0,346 \mathrm{x} 2+0,001$ x3 Sehingga dapat disimpulakan jika kecepatan sepeda motor mempengaruhi jumlah kecelakaan.

Untuk kendaraan ringan hasil uji korelasi dan regresi linear didapatkan nilai koefisien korelasi ( $r$ ) adalah 0.56 yang terletak pada $0,40 \leq r \leq 0.60$ dan koefisien determinan (R2) adalah 0.314 atau sama dengan 31,4\%. Angka tersebut mengandung arti bahwa jumlah kecelakaan dipengaruhi oleh kecepatan sebsar 31,4\%. Hasil persamaan regresi yaitu y = $-1,723+0.048 x$ yang artinyajika setiap penambahan kecepatan sebesar $1 \%$ maka jumlah kecelakaan akan meningkat sebesar 0,048. Dapat disimpulkan jika hubungan antara kecepatan dengan kecelakaan pada kendaraan ringan tidak berpengaruh secara signifikat sesuai dengan persyaratan yaitu nilai sig $\alpha>0,05$. Sama Halnya untuk kendaraan berat hasil uji korelasi dan regresi linear didapatkan nilai koefisien korelasi (r) adalah 0.505 yang terletak pada $0,40 \leq \mathrm{r} \leq 0.60$ dan koefisien determinan (R2) adalah 0.255 atau sama dengan 25,5\%. Angka tersebut mengandung arti bahwa jumlah kecelakaan dipengaruhi oleh kecepatan sebesar $25,5 \%$. Hasil persamaan regresi yaitu $y=-1,940+0.111 x$ yang artinya jika setiap penambahan kecepatan sebesar 1\% makajumlah kecelakaan akan meningkat sebesar 0,111. Dapat disimpulkan jika hubungan antara kecepatan dengan kecelakaan pada kendaraan berat tidak berpengaruh secara signifikat sesuai dengan persyaratan yaitu nilai sig $\alpha>0,05$.

Berdasarkan uji korelasi dan regresi pada kendaraan ringan dan kendaraan berat di- 
dapatkan kesimpulan jika kendaraan ringan dan berat kecepatan tidak berpengaruh terhadap kecelakaan karena didapatkan nilai koefisien determinasi LV $=31,4 \%$ dan HV = $25,5 \%$ dibawah $60 \%$ sehingga didapat untuk di generalisasikan. Selaras dengan penelitian

\section{SIMPULAN}

Dari hasil analisis penelitian yang dilakukan, maka didapakah keseimpulan sebagai berikut ini:

1.Karakteristik kecelakaan yang terjadi pada Ruas Jalan Pantura Tuban - Widang KM 0,00-KM 29,00 adalah :

a. Berdasarkan tahun kejadian kecelakaan yang paling banyak pada tahun 2016 yaitu 156 kejadian.

b. Berdasarkan kendaraan yang terlibat yang paling banyak adalah kendaraan roda 2 (sepeda motor) yaitu 513 kendaraan atau 54,02\%.

c. Berdasarkan tingkat keparahan korban, korban yang paling banyak yaitu luka ringan sebanyak 651 korban atau $81,78 \%$.

d. Berdasarkan waktu terjadinya kecelakaan paling tinggi terjadi pada hari kamis sebanyak 79 kejadian atau 15,52\% akan tetapi setiap hari juga berpotensi terjadi kecelakaan. Sedangkan berdasarkan jam, yang paling sering yaitu pada pukul 06.00-12.00 sebanyak 165 kejadian atau 32,16\%.

e. Berdasarkan usia pelaku, yang paling sering terlibat kecelakaan yaitu usia 15-30 tahun sebanyak 384 korban atau 48,73\%. Sedangakan untuk jenis kelamin didomi nasi oleh laki-laki sebanyak 583 orang atau 73,98\%.

f. Berdasarkan tipe/jenis tabrakan, yang paling dominan adalah tabrak Depan-Samp ing sebanyak 152 kejadian atau $28,68 \%$.

g. Faktor penyebab kecelakaan yang paling dominan adalah akibat kesalahan manu sia atau faktor pengemudi sebanyak 2844 kejadian atau $91,56 \%$.

2. Lokasi titik rawan kecelakaan lalu lintas (black spot)

a. Berdasarkan metode tingkat kecelakaan didapatkan lokasi blackspot pada STA $88+000-89+000$, STA $86+000-87+000$, STA $85+000-86+000$, STA $78+000-$ 79+000, STA 77+000-78+000, dan STA 71+000-72+000.

b. Berdasarkan metode tingkat fatalitas didapatkan lokasi blackspot pada STA $86+000-87+000$, STA 77+000-78+000, SAT 73+000-72+000, dan STA 71+000$72+000$.

c. Berdasarkan metode Angka Ekivalen Kecelakaab (AEK) didapatkan lokasi blackspot pada STA $88+000-89+000$, STA $86+000-87+000$, STA $85+000-86+000$, STA $83+000-84+000$, STA $78+000-79+000$, STA $77+000-78+000$, dan STA $71+000-72+000$.

d. Berdasarkan metode cumulative summary didapatkan lokasi black spot pada STA $88+000-89+000$, STA $86+000-87+000$, STA $85+000-86+000$, STA $78+000-$ 79+000, STA 77+000-78+000, dan STA 71+000-72+000. 
3. Hubungan Antara Kecepatan dengan Kecelakaan.

Analisis Hubungan antara kecepatan dengan kecelakaan pada ruas jalan raya Pantura Tuban-Widang KM 0,00-KM 29,00 memiliki hubungan dengan kategori kuat pada kendaraan sepeda motor. Dibuktikan dengan uji korelasi terletak pada interval $0.60 \leq \mathrm{r} \leq 0.80$ untuk variabel bebas (kecepatan 85 persentil) dan variabel terikat (jumlah kecelakaan) dan ratarata kecepatan berdasarkan uji Z melaju diatas kecepatan $80 \mathrm{~km} / \mathrm{jam}$. Model persamaan terbaik kendaraan sepeda motor adalah model polynomial orde 3 dengan nilai $\mathrm{R} 2=0.705$ pada persamaan matematis $Y=-871,61+29,294 x-0,346 \times 2+0,001 \times 3$. Sedangkan untuk kendaraan ringan dan kendaraan berat memiliki hubungan yang sedang dan nilai koefisien korelasi pada interval $0.40 \leq \mathrm{r} \leq 0.60$ sehingga diabaikan atau dianggap tidak memiliki hubungan.

\section{DAFTAR RUJUKAN}

Aditriansyah, H. 2018. Analisis Kecelakaan Lalu Lintas Pada Ruas Jalan Batu Ampar Kota Batam dengan Metode Accident Rate. Tugas Akhir, Jurusan Teknik Sipil dan Perencanaan Universitas Islam Indonesia 2018.

Andini dan Fauziah. 2019. Kajian Angka Kecelakaan dan Lokasi Blackspot pada Ruas Jalan Yogyakarta-Bantul. Jurnal Skripsi. Universitas Islam Indonesia.

Badan Pusat Statistik Kabupaten Tuban. 2019. Kabupaten Tuban dalam Angka.Tuban: BPS Kabupaten Tuban.

Direktorat Jenderal Bina Marga. 1997. Manual Kapasitas Jalan Indonesia. Jakarta se latan: Direktorat Jenderal Bina Marga.

Departemen Keselamatan Transportasi Darat. 2007. Pedoman Operasi Accident Blackspot Investigation Unit/Unit Penelitian Kecealakaan Lalu Lintas (ABIU/UPK). Jakarta: Direktorat Keselamatan Transportasi Darat.

Departemen Permukiman dan Prasarana Wilayah. 2004. Penagganan Lokasi Rawan Kecelakaan Lalu Lintas. Jakarta.

Fahza,A. 2019. Analisis Daerah Rawan Kecelakaan Lalu lintas pada Ruas Jalan Tol Surabaya-Gempol. Jurnal Teknik ITS Vol.8, No.1, (2019) ISSN:2337-3539.

Hasan, M I. 2002. Pokok-pokok Materi statistika 2 (Statistik Interferensif) Edisi kedua. Jakarta: Bumi aksara

Herawati. 2014. Karakteristik dan Penyebab Kecelakaan Lalu lintas di Indonesia tahun 2012. Jurnal Penelitian Perhubungan, Volume 26 No 3 Maret 2014.

Hobbs, F. D.1995. Perencanaan dan Teknik Lalu lintas Edisi kedua. Diterjemahkan oleh Suprapto T M dan Waldijono. Yogyakarta: Gajah Mada University Press.

Intari, Dwi Esti dkk. 2019. Analisis Kecelakaan Lalu Lintas dan Biaya Kecelakaan Ma terial Pada Ruas Jalan Nasional. Jurnal Fondasi, Volume 8 No 1 tahun 2019.

Johnson, R. A. 2010. Statistics Principles and Methods Sixth Edition. Unites States of America: John Wiley \& Sons, Inc.

Kementrian Perhubungan. 2015. Peraturan Menteri Perhubungan Nomor PM 111 Tahun 2015 tentang Tata cara Penerapan Batas Kecepatan yang membagi batas kecepatan pada masing-masing lingkungan. Jakarta: Kementrian Perhubungan. 
Oglesby,C H. 1998. Teknik jalan raya, Edisis Keempat. Jakarta: Erlangga.

Pignataro, L.J (1973). Traffis Eingineering Theory and Practice. New Jersey.

Republik Indonesia. 2009. Undang-undang Republik Indonesia Nomor 22 Tahun 2009 tentang Lalu lintas dan Angkutan Jalan. Jakarta.

Republik Indonesia. 1993. Peraturan Pemerintah Nomor 43 Tahun 1993 tentang Prasa rana dan Lalu lintas Jalan. Jakarta.

Republik Indonesia. 1993. Peraturan Pemerintah Nomor 44 Tahun 1993 tentang Kenda raan dan Pengemudi. Jakarta.

Sugiyanto. 2012. Metode Penelitian Kuantitatif, Kualitatif, dan RAB. Bandung: Alfa beta.

Warpani, S. 2002. Pengelolaan lalu lintas dan Angkutan Jalan. Bandung: ITB Press. Wijaya dan Widyastuti 2016. Analisis Kecelakaan Lalu lintas Studi Kota Denpasar. Surabaya: Institut Tenologi Sepuluh Nopember.

Wiraguna,dkk. 2017. Analisis Daerah Dan Titik Rawan Kecelakaan Pada Ruas Ja lan Kolektor Sekunder di Kota Surakarta. E-Jurnal Matriks Teknik Sipil/Desember 2017/1207.

Yandi,dkk. 2020. Analisis Karakteristik Kecelakaan Lalu lintas pada Jalan Yos Sudarso Kota Pekanbaru. Jurnal teknik volume 14 Nomor 1 Edisi April 2020 Halaman 17-21. 
JURNAL BANGUNAN, VOL. 26, NO.1, MARET 2021: 45-62 